\title{
PENGEMBANGAN MODEL PEMBELAJARAN ETNOLINGUISTIK BERBASIS NILAI-NILAI ISLAM NUSANTARA UNTUK MAHASISWA PGSD
}

\section{Murtono, dan Muhammad Noor Ahsin}

Universitas Muria Kudus

Email: murtono@umk.ac.id; noor.ahsin@umk.ac.id

\begin{tabular}{|c|c|}
\hline Info Artikel & Abstract \\
\hline $\begin{array}{l}\text { Sejarah Artikel: } \\
\text { Diterima 1 April } 2019 \\
\text { Direvisi 31 Mei } 2019 \\
\text { Disetujui } 1 \text { Juni } 2019\end{array}$ & $\begin{array}{l}\text { The purpose of this study was (1) to apply the ethnolingistic learning model based on } \\
\text { Islamic values of the nusantara to students of Elementary School Teacher Education } \\
\text { (PGSD). This research is development research. The stages in this study took seven steps } \\
\text { from the ten } R \text { \& D steps offered by Gall and Borg. The data to be collected in this study is } \\
\text { data that shows the teaching material and design of ethnolinguistic learning based on } \\
\text { Islamic Nusantara values for PGSD students. The product trial subjects were lecturers and }\end{array}$ \\
\hline $\begin{array}{l}\text { Keywords: } \\
\text { Model, Learning, } \\
\text { Ethnolinguistics, Students. }\end{array}$ & $\begin{array}{l}\text { PGSD students at Muria Kudus University. The results of this study are ethnolinguistic } \\
\text { learning models based on Islamic values of the nusantara and teaching materials. Based } \\
\text { on the results of the discussion it can be concluded that the ethnolinguistic learning model } \\
\text { based on Islamic values of the nusantara and ethnolinguistic teaching materials based on } \\
\text { Islamic values of the nusantara are appropriate and meet the requirements to be used as }\end{array}$ \\
\hline
\end{tabular}

\begin{abstract}
Abstrak
Tujuan dari penelitian ini adalah (1) menerapkan model pembelajaran etnolinguistik berbasis nilai-nilai islam nusantara untuk mahasiswa Program Studi Pendidikan Guru Sekolah Dasar (PGSD). Penelitian ini merupakan penelitian pengembangan. Tahapan dalam penelitian ini mengambil tujuh langkah dari sepuluh langkah $\mathrm{R} \& \mathrm{D}$ yang ditawarkan oleh Gall dan Borg. Data yang ingin dikumpulkan dalam penelitian ini adalah data yang yang menunjukkan bahan ajar dan desain pembelajaran etnolinguistik berbasis nilai-nilai Islam Nusantara untuk mahasiswa PGSD. Subjek uji coba produk adalah dosen dan mahasiswa PGSD Universitas Muria Kudus. Hasil penelitian ini model pembelajaran etnolinguistik berbasis nilai Islam Nusantara dan bahan ajar. Berdasarkan hasil pembahasan dapat diambil simpulan bahwa model pembelajaran etnolinguistik berbasis nilai-nilai islam nusantara dan bahan ajar etnolinguistik berbasis nilai-nilai islam nusantara sudah layak dan memenuhi syarat untuk digunakan sebagai model pembelajaran dan bahan ajar.
\end{abstract}

(C) 2019 Universitas Muria Kudus 
Murtono, M., dan Ahsin, Muhammad Noor

PENGEMBANGAN MODEL PEMBELAJARAN ETNOLINGUISTIK BERBASIS NILAI-NILAI ...

REFLEKSI EDUKATIKA: Jurnal Ilmiah Kependidikan, Volume 9, Nomor 2, Juni 2019, hlm 217-222

\section{PENDAHULUAN}

Dalam pembelajaran di Sekolah Dasar, materi tentang Etnolinguistik ada. Bahkan dalan kuliah mahasiswa PGSD pun ada mata kuliah etnolinguistik. Namun sayangnya, pengembangan model pembelajaran tentang etnolinguistik untuk mahasiswa Pendidikan Guru Sekolah Dasar belum banyak dilakukan, untuk pembelajaran siswa sekolah dasar juga belum banyak. Pembelajaran etnolinguistik dan pemahaman nilai-nilai Islam Nusantara penting kiranya disampaikan pada peserta didik. Jadi perlu kiranya dikembangkan model pembelajaran etnolinguistik berbasis nilai Islam Nusantara untuk pembelajaran.

$\begin{array}{cccr}\text { Dalam } & \text { konteks } & \text { itulah maka } \\ \text { pengembangan } & \text { model } & \text { pembelajaran }\end{array}$ etnolinguistik berbasis kooperatif untuk pembelajaran perlu diterapkan. Model pembelajaran etnolinguistik berbasis nilai Islam Nusantara untuk pembelajaran bagi mahasiswa PGSD ini diharapkan mampu memberikan solusi kaitannya untuk menciptakan iklim pembelajaran yang lebih kreatif dan inovatif.

Model pembelajaran adalah prosedur atau pola sistematis yang digunakan sebagai pedoman untuk mencapai tujuan pembelajaran di dalamnya terdapat strategi, teknik, metode, bahan, media dan alat penilaian pembelajaran (Afandi, Muhammad dkk, 2013). Oleh karena itu, dalam model pembelajaran pastilah disiapkan sintak pembelajarannya. Model pembelajaran adalah blue print learning (cetak biru pembelajaran).

Islam adalah agama rahmatan lil 'alamain yang bersifat universal. Artinya, misi dan ajaran islan tidak hanya ditujukan kepada satu kelompok atau negara, melainkan seluruh umat manusia, bahkan jagat raya (Luthfi, 2016). Berdasarkan pemaparan tersebut maka peneliti tergerak hati untuk membuat penelitian pengembangan model pembelajaran etnolinguistik berbasis nilai-nilai Islam Nusantara untuk mahasiswa Program Studi Pendidikan Guru Sekolah Dasar. Tujuan pada penelitian ini yakni mengetahui penerapan model pembelajaran etnolinguistik berbasis nilai-nilai Islam Nusantara untuk mahasiswa Pendidikan Guru Sekolah Dasar.

Secara umum dikatakan model adalah pola (contoh, acuan, ragam) dari sesuatu yang akan dibuat atau dihasilkan. Model merupakan gambaran mental yang membantu memahami sesuatu yang tidak dapat dilihat atau pengalaman langsung (Dorin, Demmin, dan Gabel dalam Mergel, 1998: 2). Sementara itu, Dilworth (1992: 74) mendefinisikan model sebagai representasi abstrak dari proses, sistem, atau subsistem yang konkret. Model digunakan dalam seluruh aspek kehidupan. Model bermanfaat dalam mendeskripsikan pilihan-pilihan dan dalam menganalisis tampilan pilihan-pilihan tersebut.

Selaras dengan pengertian ini, model pembelajaran memiliki batasan yang berbedabeda sesuai dengan bidang ilmu atau pengetahuan yang mengadopsinya. Salah satu definisi model dikemukakan Dewey (dalam Joyce, 2009: 14), model pembelajaran adalah suatu rencana atau pola yang digunakan dalam penyusunan kurikulum, mengatur materi siswa, dan memberi petunjuk kepada pengajar di dalam kelas dalam setting pengajaran atau setting lainnya. Model pembelajaran adalah kerangka konseptual yang melukiskan prosedur yang sistematis dalam mengorganisasikan pengalaman belajar untuk mencapai tujuan tertentu dan berfungsi sebagai pedoman bagi para perancang pembelajaran dan para pengajar dalam merencanakan dan melaksanakan aktivitas pembelajaran (Suryaman, 2004: 66). Oleh karena itu, dalam model pembelajaran pastilah disiapkan sintak pembelajarannya. Model pembelajaran adalah blue print learning (cetak biru pembelajaran).

Terdapat beberapa model pembelajaran yang berpijak dari paradigma berpikir dalam pendidikan yang telah dikembangkan di dunia maju. Joyce (2009) mengelompokkan model pembelajaran ini minimal ada empat kelompok mendasar, yaitu: (1) model pemprosesan informasi (2) model Pribadi, (3) model interaksi sosial, dan (4) model sistem perilaku.

Sementara itu ahli yang lain menyebutkan minimal ada tiga jenis model pembelajaran mendasar, yaitu: competitive learning model, individual learning model, dan cooperative learning model (Slavin, 1995).

Etnolinguistik secara etimologis terbentuk dari akar kata "Etnologi" dan "Linguistik". Etnologi perupakan ilmu tentang unsur atau masalah kebudayaan suku bangsa dan masyarakat pendidikan suatu daerah di seluruh dunia secara komparatif dengan tujuan mendapatkan pengertian tentang sejarah dan proses evolusi serta penyebaran kebudayaan umat manusian di muka bumi. Sedangkan 
linguistik memiliki pengertian telaah ilmiah mengenai bahasa manusia (Martinet, 1987) dalam Chaer (2007). Jadi, dapat disimpulkan etnolinguistik adalah studi tentang proses terbentuknya kebudayaan dan keterkaitannya dengan bahasa (Putra, 1997:1).

Dalam buku Islam Kita Islam Nusantara, Lima Nilai Dasar Islam Nusantara karya Romli menyatakan Islam Nusantara bukan istilah yang baru, namun kembali populer setelah dilemparkan ke publik oleh Ketua Umum PBNU, KH Said Aqil Siradj dalam pembukaan acara Istighotsah Menyambut Ramadhan dan Pembukaan Munas Alim Ulama NU, Minggu, 14 Juni 2015 di Masjid Istiqlal, Jakarta.

Menurut KH Said Aqil Siradj, NU akan terus memperjuangkan dan mengawal model Islam Nusantara. Istilah Islam Nusantara yang ia maksud merujuk pada fakta sejarah penyebaran Islam di wilayah Nusantara yang disebutnya "dengan cara pendekatan budaya, tidak dengan doktrin yang kaku dan keras, Islam Nusantara ini didakwahkan merangkul budaya, melestarikan budaya, menghormati budaya, tidak malah memberangus budaya.

"Islam Nusantara" memiliki perbedaan dari "Islam di Nusantara". Kata Nusantara pada istilah yang pertama adalah sifat, dalam bahasa pesantren disebut "mudhafun ilaihi" - Ia menyifati kata Islam, dalam istilah lain, "Islam Nusantarawi”. Sedangkan pada istilah yang nomor dua, Islam Nusantara hanya menunjukkan nusantara hanya sebagai tempat saja yang tidak memiliki hubungan, apalagi pengaruh terhadap islam. Oleh karena itu Islam nusantara bisa dipahami sebagai Islam dengan corak, warna, kekhasan, keunikan, karakter, budaya Nusantara (Romli, 2016).

Lima nilai dasar islam nusantara. Pertama, yaitu memahami Muslim sebagai identitas kolektif atas siapa pun yang menganggao dirinya muslim yang meyakini Allah SWT sebagai satu-satunya Tuhan dan nabi Muhammad SAW sebagai Rosul (utusan) Allah SWT, terlepas dari perbedaan tafsir atas agama Islam. Mengenai perbedaan tafsir itu, kami berpandangan biarlah itu urusan individu yang bersangkutan dengan Tuhannya, yang tal patut diitervensi oleh negara atau pihak lainnya.

Kedua, memperjuangkan nilai esensial Islam yang tidak mendiskriminasi manusia baik atas dasar suku, gender, ras, disabilitas, paham agama, dan sebagainya. kami menolak segala bentuk kebencian baik yang berwujud ucapan (hate speech), tulisan dan tindakan terhadap suku, gender, ras, disabilitas, agama, aliran, paham keagamaan apapun, karena bertentangan dengan nilai-nilai esensial agama Islam.

Ketiga, berbagai hal yang bertentangan dengan prinsip hak-hak asasi manusia (HAM) maka potensial bertentangan pula dengan nilai esensial islam yang kami yakini. Keempat, berbagai hal yang bertentangan dengan prinsip demokrasi dan kearifan lokal di Nusantara, maka potensial bertentangan pula dengan nilai-nilai esensial Islam yang kami yakini. Kelima, berbagai hal yang bertentangan dengan Pancasila dan pilar-pilar keindonesiaan, maka potensial bertentangan pula dengan nilai-nilai esensial Islam yang kami yakini (Romli, 2016).

\section{METODE PENELITIAN}

Pendekatan yang dilakukan pada penelitian ini menggunakan metode penelitian dan pengembangan (research and development $/ R \& D)$. Menurut Sugiyono (2011:407) metode penelitian pengembangan adalah metode penelitian yang digunakan untuk menghasilkan produk tertentu, dan menguji keefektifan produk tersebut.

Model penelitian dan pengembangan bahan ajar ini menggunakan gagasan Borg dan Gall dengan tahapan diantaranya penelitian dan pengumpulan informasi awal, perencanaan, pengembangan format produksi awal, uji coba awal, revisi produk, uji coba lapangan, revisi produk akhir, dan desiminasi dan implementasi. Berkaitan dengan adanya keterbatasan waktu penelitian, maka penelitian ini belum sampai pada desiminasi dan implementasi, penelitian yang dilakukan hanya menghasilkan revisi produk akhir.

\section{HASIL DAN PEMBAHASAN}

Berdasarkan hasil observasi dan hasil wawancara kepada mahasiswa Program Studi Pendidikan Guru Sekolah Dasar FKIP Universitas Muria Kudus diperoleh data bahwa pembelajaran etnolinguistik belum ada buku ajar yang dibuat oleh pengampu mata kuliah. Selain itu kajian dan nilai-nilai Islam Nusantara bisa menjadi masukan dan bisa diterapkan untuk diaplikasikan dapat pembelajaran etnolinguistik. Untuk itu perlu dikembangkan model pembelajaran etnolinguisitik berbasis nilai-nilai Islam Nusantara. 
Murtono, M., dan Ahsin, Muhammad Noor

PENGEMBANGAN MODEL PEMBELAJARAN ETNOLINGUISTIK BERBASIS NILAI-NILAI ...

REFLEKSI EDUKATIKA: Jurnal Ilmiah Kependidikan, Volume 9, Nomor 2, Juni 2019, hlm 217-222

Pertama, tahap pengumpulan informasi awal atau analisis kebutuhan dilakukan untuk mendapatkan informasi mengenai mengenai kebutuhan model pembelajaran yang menarik untuk pembelajaran mata kuliah etnolinguistik berbasis nilai-nilai Islam Nusantara. Data yang didapatkan diperoleh dengan melakukan wawancara kepada dosen PGSD yang mengajar mata kuliah etnolinguistik di Prodi Pendidikan Guru Sekolah Dasar Universitas Muria Kudus.

Kedua, perencanaan yaitu dilakukan dengan kegiatan merencanakan pembuatan bahan ajar berdasarkan informasi yang diperoleh di lapanga, dalam tahapan ini ada pretes. Pretes berisi pertanyaan-pertanyaan tentang tentang pemahaman etnolinguistik, wawasan islam nusantara, nilai-nilai Islam Nusantara dan sebagainya.

Ketiga, pengembangan format model awal, Tahap ini dilakukan dengan mendiskusikan langkah-langkah model pembelajaran etnolinguistik berbasis nilai Islam Nusantara dengan cooperative learning. Ada ahli yang dimintai kontribusi atau pendapatnya mengenai pengembangan model ini yang juga melibatkan dosen.

Keempat, uji coba tahap awal. Model pembelajaran etnolinguistik berbasis nilai-nilai islam nusantara yang telah dikembangkan diujicobakan kepada mahasiswa. Uji coba awal menghasilkan beberapa poin penting yaitu: (1) hasil wawancara kepada dosen tentang bentuk model pembelajaran etnolinguistik berbasis nilainilai Islam Nusantara; (2) observasi yang dilakukan oleh pengamat tentang kondisi pembelajaran; dan 3) angket mahasiswa yang berisi tentang pertanyaan yang berkaitan tentang model dan bahan ajar. Uji coba awal diujicobakan kepada mahasiswa mata kuliah etnolinguistik Semester VI.

Kelima, revisi produk, atau revisi model pembelajaran, yaitu memperbaiki model dan draf bahan ajar berdasarkan hasil uji coba awal. Keenam, dilakukan uji coba terbatas ini menghasilkan data kuantitatif dari hasil belajar mahasiswa yaitu pemahaman mahasiswa tentang materi etnolinguistik berwawasan nilai-nilai Islam Nusantara.

Ketujuh, revisi produk model dan draf bahan ajar berupa perbaikan-perbaikan model dan draf bahan ajar berdasarkan hasil uji coba terbatas. Hal ini dilakukan dengan tujuan untuk menghasilkan model pembelajaran etnolinguistik dan bahan ajar untuk perbaikan pada tahap berikutnya. Kedelapan, uji lapangan kepada mahasiswa Pendidikan guru Sekolah dasar Universitas Muria Kudus semester VI kelas B dengan melibatkan subjek penelitian, disertai wawancara, observasi, dan penyampaian angket yang telah diberikan. Kesembilan, yaitu revisi produk akhir, revisi model dan draft bahan ajar, kegiatan revisi yang dikerjakan berdasarkan uji coba lapangan yang telah dilakukan kepada mahasiswa Pendidikan Guru Sekolah dasar Universitas Muria Kudus.

Pembelajaran etnolinguistik berbasis nilai-nilai Islam Nusantara menerapkan model pembelajaran dengan konsep Cooperative Learning. Pembelajaran dengan Cooperative Learning merupakan suatu pembelajaran kelompok dengan jumalah peserta didik antara 35 orang dengan gagasan untuk saling memotivasi antara anggotanya untuk saling membantu agar tercapainya suatu tujuan pembelajaran yang maksimal. Ciri-ciri pembelajaran dengan konseop Cooperative Learning adalah: (a) untuk menuntaskan materi belajar, mahasiswa belajar dalam kelompok secara bekerja sama; (b) kelompok dibentuk dari mahasiswa yang memiliki kemampuan tinggi, sedang, dan rendah; (c) jika dalam kelas terdapat mahasiswa yang heterogen ras, suku, budaya, dan jenis kelamin, maka diupayakan agar tiap kelompok terdapat keheterogenan tersebut; (d) penghargaan lebih diutamakan pada kerja kelompok daripada perorangan (Kurnia, Rizka Dhini dkk, 2014)

Prosedur penyusunan model pembelajaran etnolinguistik berbasis nilai-nilai Islam Nusantara. Prosedur dimaksud yaitu. Pertama, pengembangan model Pembelajaran etnolinguistik berbasis nilai-nilai Islam Nusantara, pada tahap awalnya dirumuskan berdasarkan data yang dikumpulkan melalui wawancara kepada dosen yang mengampu mata kuliah etnolinguistik.

Kedua, tahap berikutnya perumusan model final yang dilakukan secara partisifatif dengan melibatkan seluruh pemangku kepentingan (stake-holder) terkait, Dosen, mahasiswa, tim peneliti. Ketiga, perumusan model. Tahap akhir dilaksanakan melalui diskusi kelompok dengan dosen dan tim peneliti dalam forum FGD. Di $F G D$ ini akhirnya disepakti model yang akan diimplementasikan.

Langkah-langkah pembelejaran model pembelajaran etnolinguistik berbasis nilai Islam 
Murtono, M., dan Ahsin, Muhammad Noor

PENGEMBANGAN MODEL PEMBELAJARAN ETNOLINGUISTIK BERBASIS NILAI-NILAI ... REFLEKSI EDUKATIKA: Jurnal Ilmiah Kependidikan, Volume 9, Nomor 2, Juni 2019, hlm 217-222

Nusantara terdiri dari 6 fase. Seperti terlihat pada tabel berikut ini.

Tabel 3.1 Langkah-langkah dalam model pembelajaran etnolinguistik

\begin{tabular}{|c|c|c|c|c|}
\hline $\begin{array}{l}\mathrm{N} \\
\mathrm{o}\end{array}$ & Fase & $\begin{array}{l}\text { Indikator/ } \\
\text { Langkah }\end{array}$ & Kegiatan Dosen & Keterangan \\
\hline 1 & 1 & $\begin{array}{l}\text { Menyampaik } \\
\text { an tujuan } \\
\text { dan } \\
\text { persiapan } \\
\text { mahasiswa }\end{array}$ & $\begin{array}{l}\text { Menjelaskan tujuan } \\
\text { pembelajaran dan } \\
\text { mempersiapkan } \\
\text { mahasiswa siap belajar }\end{array}$ & $\begin{array}{l}\text { Menyampaikan tujuan dan mempersiapkan } \\
\text { mahasiswa. Dosen mengklasifikasi maksud } \\
\text { pembelajaran etnolinguistik berbasis nilai-nilai } \\
\text { Islam Nusantara }\end{array}$ \\
\hline 2 & 2 & $\begin{array}{l}\text { Menyajikan } \\
\text { Informasi } \\
\text { materi }\end{array}$ & $\begin{array}{l}\text { Mempresentasikan } \\
\text { kepada mahasiswa } \\
\text { secara verbal }\end{array}$ & $\begin{array}{l}\text { Dosen menjelaskan materi pembelajaran } \\
\text { etnolinguistik }\end{array}$ \\
\hline 3 & 3 & $\begin{array}{l}\text { Membagi } \\
\text { kelompok }\end{array}$ & $\begin{array}{l}\text { Memberikan } \\
\text { penjelasan kepada } \\
\text { mahasiswa tentang } \\
\text { cara pembentukan tim } \\
\text { kelompok satu } \\
\text { kelompok terdiri dari } \\
\text { 3-5 mahasiswa }\end{array}$ & $\begin{array}{l}\text { Dosen menjelaskan bahwa mahasiswa harus saling } \\
\text { bekerja sama di dalam kelompok mata kuliah } \\
\text { etnolinguistik. Penyelesaian. Tugas kelompok harus } \\
\text { merupakan tugas kelompok. Jangan sampai ada } \\
\text { anggota yang menggantungkan tugas kelompok } \\
\text { kepada individu lainnya }\end{array}$ \\
\hline 4 & 4 & $\begin{array}{l}\text { Membantu } \\
\text { kerja tim dan } \\
\text { belajar }\end{array}$ & $\begin{array}{l}\text { Membantu tim-tim } \\
\text { belajar selama } \\
\text { mahasiswa } \\
\text { mengerjakan tugas }\end{array}$ & $\begin{array}{l}\text { Dosen perlu mendampingi kelompok atau tim- } \\
\text { tim belajar. Bantuan dapat diberikan berupa } \\
\text { petunjuk, pengarahan dan sebagainya. }\end{array}$ \\
\hline 5 & 5 & $\begin{array}{l}\text { Mengevalua } \\
\text { si }\end{array}$ & $\begin{array}{l}\text { Menguji pengetahuan } \\
\text { mahasiswa mengenai } \\
\text { materi pembelajaran } \\
\text { kelompok, kemudian } \\
\text { presentasi }\end{array}$ & $\begin{array}{l}\text { Pengajar melakukan upaya evaluasi yang } \\
\text { konsisten dengan tujuan pembelajaran } \\
\text { etnolinguistik berbasis nilai-nilai islam } \\
\text { nusantara }\end{array}$ \\
\hline 6 & 6 & $\begin{array}{l}\text { Memberikan } \\
\text { penghargaan } \\
\text { atau reward } \\
\text { kepada tim }\end{array}$ & $\begin{array}{l}\text { Mempersiapkan cara } \\
\text { untuk mengakui usaha } \\
\text { dan presentasi } \\
\text { individu maupun } \\
\text { kelompok }\end{array}$ & $\begin{array}{l}\text { Dosen menyiapkan rencana reward yang akan } \\
\text { diberikan kepada mahasiswa. }\end{array}$ \\
\hline
\end{tabular}

Berdasarkan hasil wawacara dengan dosen pengampu mata kuliah, pengembangan model pembelajaran etnolinguistik berbasis nilainilai Islam Nusantara sudah baik. Model ini diharapkan dapat menjadi alternatif penerapan model pembelajaran inovatif untuk mata kuliah etnolinguistik.

Selain itu, Berdasarkan kriteria penilaian bahan etnolinguistik berbasis nilai-nilai islam nusantara dikatakan baik karena persentasenya lebih dari 78\%. Berdasarkan keterangan skor, kualitas bahan ajar etnolinguistik berbasis nilainilai Islam Nusantara dikatakan baik apabila skor lebih dari $76 \%$. Skor penilaian dua ahli yaitu $90 \%$ dan $82,5 \%$. Dengan demikian hasil itu disimpulkan hasil yang baik.

Dalam penelitian ini, untuk memahami dan mengetahui tingkat hasil kualitas bahan ajar etnolinguistik berbasis nilai Islam Nusantara yang dikembangkan, maka dari itudilakukan upaya uji kualitas. Dalam uji kualitas bahan ajar bahasa etnolinguistik berbasis nilai-nilai islam nusantara melalui tahapan penilaian dari para pakar yang berkompeten. Para pakar yang ditunjuk yaitu pertama seoarang ahli pembelajaran bahasa dan seoarang ahli desain grafis dan ahli bahasa.

Dalam penelitian ini, untuk mengetahui tingkat kualitas bahan ajar etnolinguistik berbasis nilai-nilai Islam Nusantara yang dikembangkan, maka dilakukan uji kualitas. Uji kualitas bahan ajar bahasa etnolinguistik berbasis nilai-nilai Islam Nusantara melalui penilaian pakar. Para pakar meliputi: seorang ahli pembelajaran bahasa Indonesia dan seorang ahli desain grafis dan ahli bahasa.

Berdasarkan penilaian kualitas grafik bahan ajar etnolinguistik berbasis nilai-nilai 
Murtono, M., dan Ahsin, Muhammad Noor

PENGEMBANGAN MODEL PEMBELAJARAN ETNOLINGUISTIK BERBASIS NILAI-NILAI ...

REFLEKSI EDUKATIKA: Jurnal Ilmiah Kependidikan, Volume 9, Nomor 2, Juni 2019, hlm 217-222

Islam Nusantara meliputi ukuran sampul, tampilan sampul, ilustrasi, komposisi, tipografi dan sebagainya secara total berkualitas baik. Hal itu karena persentasenya lebih dari $76 \%$. Jadi dapat disimpulkan bahwa kualitas grafik bahan ajar etnolinguistik yang berbasis nilai islam Nusantara sangat layak digunakan sebagai bahan ajar bahasa etnolinguistik berbasis nilai Islam Nusantara.

\section{PENUTUP}

Berdasarkan hasil pembahasan dapat diambil kesimpulan bahawa model pembelajaran etnolinguistik berbasis nilai Islam Nusantara dan bahan ajar etnolinguistik berbasis nilai-nilai Islam Nusantara sudah kiranya sudah sangat layak untuk digunakan sebagai model pembelajaran dan bahan ajar. Hal itu disebabkan oleh hasil penilaian para ahli atau reviewer ratarata menghasilkan persentase dengan nilai lebih dari $76 \%$. Jadi dapat disimpulkan model pembelajaran etnolinguistik berbasis nilai Islam Nusantara dan bahan ajar ajar etnolinguistik berbasis nilai Islam Nusantara sudah layak digunakan untuk pembelajaran.

\section{DAFTAR PUSTAKA}

Afandi, Muhamad dkk. 2013. Model dan Metode Pembelajaran di Sekolah. Semarang: Unissula Press.

Dilworth, J.B. 1992. Operations Management: Design, Planning, and Control for Manufacturing. Boston: Allyn Bacon/Pearson.

Duranti, Alessandro. 1997. Linguistic Anthropology. Cambridge: Cambridge University Press. Massachusetts USA: Blackwell Publishers.
Joyce, B., M. Weil, \& E. Calhoun. 2009. Models of Teaching (8th ed.). Boston: Allyn Bacon/Pearson.

Kasdi, Abdurrahman. 2000. Fundamentalisme Islam Timur Tengah: Akar Teologi. Kritik Wacana dan Politisasi Agama". Jurnal Tashwirul Afkar, 3.

Kurnia, Rizka Dhini dkk. 2014. "Pengembangan Model Pembelajaran Berbasis Cooperative Learning dalam Meningkatkan Motivasi Belajar Mahasiswa dan Peningkatan Mutu Lulusan Alumni Fasilkom Unsri Berbasis E-Learning (Studi Kasus: Mata Kuliah Pemrograman Web)." Jurnal Sistem Informasi, 6 (1).

Luthfi, Khabibi Muhammad. 2016. Islam Nusantara: Realsi Islam dan Budaya Lokal. Jurnal Shahih IAIN Surakarta. Vol. 1 No. 1.

Putra, Shri Ahimsa. 1997. Etnolinguistik Beberapa Bentuk Kajian. Makalah Disajikan dalam Temu Ilmiah Bahasa dan Sastra Tanggal 26-27 Maret. Yogyakarta.

Romli, Mohamad Guntur. 2016. Islam Kita Islam Nusantara, Lima Nilai Dasar Islam Nusantara. Jakarta: Ciputat School.

Slavin, Robert E. 1995. Cooperative Learning Theory, Research and Practise. Massachusett, USA: Allymand \& Bacon.

Sugiyono. 2005. Memahami Penelitian Kualitatif. Bandung: Alfabeta. 